\title{
БАТЬКІВСЬКИЙ ПЕРФЕКЦІОНІЗМ ЯК ЧИННИК ПЕРФЕКЦІОНІЗМУ СТУДЕНТСЬКОЇ МОЛОДІ
}

УдК: 159.923

\section{Завада Т.Ю.}

Викладач кафедри психології і психотерапї Українського католииького університету, м. Львів (Україна)

Анотація. Стаття присвячена висвітленню проблеми впливу стилів сімейного виховання на перфекиіонізм молоді. Проаналізовано теоретичний доробок психологічних досліджень, щуо стосуються сімейного виховання та його зв'язку з перфекціонізмом. У емпіричному дослідженні виявлено ті стилі батьківського виховання, щчо найбільш притаманні для перфекціоністів.

За допомогою регресійного аналіз виокремлено стилі сімейного виховання, щзо здійснюють вплив на формування перфекціонізму: ігнорування потреб дитини, надмірність вимог, проекція на дитину власних небажаних якостей. Також виявлено, що перфекціоністичні батьки здатні виховувати перфекціоністські орієнтації у власний дітей.

Ключові слова: перфекиіонізм, батьківський перфекиіонізм, особистість, стилі сімейного виховання, студентська молодь, авторитарний стиль виховання.

\section{Постановка проблеми та аналіз тизованих та узагальнених наукових поглядів} останніх досліджень і публікацій. Проблема на структуру перфекціонізму, розроблених перфекціонізму в психологічній літературі, теоретичних моделей та типологій, проте, все завдяки активним дослідженням за останні 2030 років, набуває наукового розквіту. В теореж досі точаться дискусії щодо амбівалентності природи даного психологічного феномену. тичному полі, існує значна кількість система- Адже, з однієї сторони перфекціоністські тен- 
денції стимулюють особистість до саморозвитку, а з іншої - пов'язані зі значними психоемоційними розладами.

В широкому сенсі, під перфекціонізмом, розуміють прагнення особистості встановлювати завищені вимоги та стандарти до результатів своєї діяльності. Проте, структура перфекціонізму $є$ більш складною, i до неї також включають постійне порівнянням себе 3 іншими людьми, приписування оточуючим людям надмірно високих очікувань, поляризоване мислення - за принципом «все або нічого», а також фіксацію на власних помилках і невдачах $[1,2,6]$. Як наслідок, така позиція супроводжується постійною самокритикою, зумовлює труднощі в отриманні задоволення від результатів діяльності, сприяє соціальній дезадаптації [2], що може бути причиною психологічних проблем, психічних чи соматичних захворювань.

Більшість науковців сходяться на думці, що виникнення перфекціонізму залежить від особливостей сімейного виховання (Р. Блатт, Д. Барнс, М. Вей, С. Волікова, I. Грачева, М. Холендер, Л. Данилевич, А. Пахт, Н. Гаранян, Р. Фрост, Г. Флетт, Д. Хамачек, К. Хорні, А. Холмогорова, Т. Юдєєва та ін.), і перфекціоністська орієнтація формується в молодшому шкільному віці, а то й раніше $[1,2,4,6,7,8]$. Стиль сімейного виховання і модель сімейних взаємостосунків «схоплюються» дитиною і впливають на фо- рмування іiі потреб, мотивів, цінностей, ідеалів, установок.

Авторитарний стиль виховання (високі вимоги, недостатня емоційна підтримка, жорстка дисципліна і т.д.) - один з основних чинників розвитку перфекціонізму [3]. Д. Хамачек вважає [9], що невротичний перфекціонізм виникає внаслідок досвіду взаємодії з батьками, які проявляють свою любов в залежності від результатів діяльності дитини. Якщо батьки не схвалюють вчинки дитини, то вона намагається стати досконалою, не лише для того, щоб уникнути незадоволення інших, але й для того, щоб нарешті прийняти себе через надлюдські зусилля і досягнення. Якщо ж батьки частково схвалюють вчинки дитини, то вона починає усвідомлювати, що лише хороше виконання діяльності визначає іiі цінність. Батьки перфекціоніста надзвичайно критичні, вимогливі і загалом, не дають достатньої підтримки [9]. Дитина повинна бути «безпомилковою», щоб задовольнити батьківські очікування і уникнути критики.

Британський клінічний психолог Р. Фрост у розробленій 6-ти компонентній структурі перфекціонізму виокремлює дві складові перфекціонізму, що стосуються батьків: «батьківська критика» (Parental Criticism) i «батьківській очікування» (Parental Expectations). Батьківські очікування (Parental Expectations) - сприйняття батьків як надто вимогливих; Батьків- 
ська критика (Parental Criticism) - сприйняття батьків як надто критичних. Однак, як відзначає Н. Г. Гаранян, залишається незрозумілим - ці батьки насправді встановлюють надто високі стандарти для своїх дітей чи діти схильні сприймати своїх батьків як таких, що встановлюють дуже високі стандарти і надто критичнi? [2]

Науковці узагальнюють чотири типи батьківської поведінки, що мають вплив на формування перфекціоністичного мислення у дитини: 1. батьки надто критичні й вимогливі; 2. батьківські очікування і стандарти надто високі; критика при цьому не пряма; 3. батьківське схвалення відсутне або ж воно непослідовне і обумовлене; 4. батькиперфекціоністи $є$ моделями для формування перфекціоністських установок і форм поведінки.

Психоаналітик С. Дж. Блатт [8] досліджувала проблему батьківського перфекціонізму, і його вплив на формування емоційних порушень у дітей. Науковець виявила, що батькам 3 високий рівнем перфекціонізму надзвичайно важко прийняти як власні успіхи, так і успіхи дітей. Таким батькам надзвичайно важко похвалити дитину за старання та досягнення, і вони часто змушують здійснювати будь-яку діяльність все більше й краще. В якості основного покарання за неуспіх може виступати відмова від батьківській любові. Дитина змушена прагнути все робити без помилок, майже ідеально, щоб задовольнити бать- ківські очікування, уникнути критики й заслужити батьківську любов.

Мета - дослідження стилів сімейного виховання, що впливають на формування перфекціонізму у студентської молоді.

\section{Виклад основного матеріалу і резуль-} татів дослідження. Для того аби виявити, яким чином, сімейне виховання впливає на формування перфекціонстских тенденцій серед студентської молоді, нами проведено дослідження серед студентів ( $\mathrm{N}=299)$ та безпосередньо їх батьків $(\mathrm{N}=149)$.

Дослідження стилю батьківського виховання здійснювалося за допомогою методики БОД (Батьків оцінюють діти), а також пропонувалося батькам заповнити модифікований Т. Завадою опитувальник перфекціонізму Н. Гаранян, А. Холмогорової.

Як свідчать результати однофакторного дисперсійного аналізу існують істотні відмінності у стилях батьківського виховання осіб 3 високим, середнім та низьким рівнями перфекціонізму. Зокрема, відмінності виявлено за такими показниками як «гіперпротекція» $(\Gamma+)$, $(\mathrm{p}=0,005), \quad$ «гіпопротекція» $(\Gamma-), \quad(\mathrm{p}=0,001)$, «недостатність обов'язків у дитини» (О-), $(\mathrm{p}=0,02)$, «надмірність вимог, заборон» $(3+)$, $(\mathrm{p}=0,02)$, «надмірність санкцій (жорсткий стиль виховання)» $(\mathrm{C}+), \quad(\mathrm{p}=0,005)$, «нестійкість стилю виховання» $(\mathrm{H}),(\mathrm{p}=0,009)$, «розширення сфери батьківських почуттів» (РБП), (p=0,01), «перевага дитячих якостей у підлітку» (ПДЯ), (p=0,004), «фобія 
втрати дитини» «нерозвиненість

(ФB) батьківських

$(\mathrm{p}=0,003)$, почуттів» (НБП), ( $=0,003)$, «проекція небажаних якостей» (ПНЯ), $(\mathrm{p}=0,05)$, «винесення конфлікту між подружжям у сферу виховання» $(\mathrm{BK}),(\mathrm{p}=0,04)$.

За допомогою тесту Шеффе з'ясовано, що всі відмінності за шкалами сімейного виховання, що виявлені за допомогою однофакторного дисперсійного аналізу переважають у осіб з високим рівнем перфекціонізму, і найменш проявляються - у групі досліджуваних 3 його низьким рівнем.

Отримані результати свідчать, що значна кількість різноманітних сімейних труднощів може бути пов'язана 3 формуванням та розвитком перфекціонізму. Зокрема, охарактеризуємо переважаючі стилі сімейного виховання у осіб з високим рівнем перфекціонізму:

Виховання перетворюється на центральну діяльність в житті батьків, якій вони присвячують власне життя (2іперпротекиія).

Дитина знаходиться на периферії уваги батьків, іiі проблеми актуальні тільки тоді, коли ситуація вже надто серйозна, недостатність уваги з боку батьків (гіпопротекиія).

Мінімальна кількість обов'язків в дитини у сім'ї (недостатність обов'язків).

Дитині в сім'ї- «все не можна». Батьки висувають велику кількість вимог, що обмежують свободу i самостійність дитини (надмірність заборон).

Батьки переконані у корисності строго- го покарання дитини, надмірно реагують навіть на дрібні проступки підлітка (надмірність санкиій).

Різка зміна стилю та методів виховання: від авторитарного - до ліберального, від надмірної уваги - до емоційної холодності (нестійкий стиль виховання).

Батьки несвідомо прагнуть, щоб дитина в сім'ї виконувала хоча б частину тих обов'язків, які повинен виконувати один з подружжя (взаємна прив'язаність, залежність, частково еротичні потреби). Часто зустрічається в сім'ях, де вихованням займається або батько, або матір (смерть одного з подружжя, розлучення, крайня незадоволеність один одним у парі тощо). Стосунки 3 дитиною є вкрай важливими, і один з батьків через потурання і домінуючу протекцію прагне назавжди прив'язати дитину, що може супроводжуватись постійними ревнощами, підозрами (розширення батьківських почуттів).

Батьки ігнорують дорослішання дитини. Їм хочеться, щоб вона завжди була «маленькою», через що зменшують кількість вимог до дитини, будують домінуючу гіперпротекцію, що може стимулювати розвиток психічного інфантилізму (перевага у дитині дитячих якостей).

Батьки (через особистісні труднощі розлади особистості, психічні порушення, або через негативний власний сімейний досвід, що базувався на емоційній холодності) слабо розуміють значення виховання в житті дитини. 
Такий стиль може проявлятись через поверхневий інтерес до дитини, небажанні мати 3 нею справи. Зазвичай, на дитину перекладається значна кількість домашніх обов'язків. Для жінок 3 нерозвиненими батьківськими почуттями характерні емансипаційні прагнення і бажання будь-яким шляхом влаштувати своє життя (нерозвиненість батьківських почуттів).

Батьки бачать в дитині ті риси характеру, які не приймають в собі. В основі стилю емоційне відторгнення, жорстоке поводження 3 дитиною (проекція небажаних якостей).

Страх, тривога батьків за життя дитини, що проявляється в невпевненості батьків, боязні помилитись, перебільшеному уявленні про «вразливість» дитини. В основі лежить домінуюча гіперпротекція (фобія втрати дитини).

Виховання перетворюється на «поле битви» конфліктуючих батьків. Вони відкрито висловлюють невдоволення один одним, керуючись «турботою про благо дитини». При цьому різниця в думках батьків найчастіше буває діаметрально протилежною: один наполягає на досить суворому вихованні з підвищеними вимогами, заборонами і санкціями, інший же - схильний «жаліти» дитини. Характерне прояв - вираження невдоволення виховними методами другого 3 подружжя. При цьому легко виявляється, що кожного цікавить не стільки те, як виховувати підлітка, скільки те, хто правий у виховних супере- чках (винесення конфлікту міжподружюм у сферу виховання).

Щоб виявити, які стилі сімейного виховання впливають на формування перфекціонізму, було проведено факторний аналіз, що дозволив виділити 4 фактори (загальна сума дисперсії-51\%).

1-й фактор (внесок в сумарну дисперсію - 26,2\%) ми інтерпретували як «емоційне відторгнення». До нього увійшли такі шкали як ігнорування потреб дитини 0,71 ; проекція небажаних якостей $-0,63$; недостатність обов'язків у дитини - 0,6; надмірна вимогливість - 0,6; перевага дитячих якостей в дитині - 0,6; гіпопротекція - 0,53.

Таким чином, це модель сім'ї, якій недостатнє виражене прагнення батьків щодо задоволення потреб дитини (в основному, це духовні потреби, потреби в емоційному контакті, спілкуванні з батьками). Також притаманна надмірність заборон, що обмежують свободу та самостійність дитини. Обов'язки ж в сім'ї зводяться до мінімуму. Дитина знаходиться на периферії уваги батьків.

\section{2-й фактор «авторитарний}

стиль» (внесок в сумарну дисперсію - 9,8\%) склали такі показники як надмірність санкцій (покарання) - 0,72; надмірність заборон 0,62 .

В такій сім’ї дитині практично нічого не дозволяють, висуваючи при цьому велику кількість вимог. Порушення батьківських заборон строго карається (фізично чи мораль- 
но). Батьки очікують значних та блискучих результатів у практично всіх сферах, в яких залучена дитина.

В 3-й фактор «ідеалізація дитини» (внесок в сумарну дисперсію - 7,7\%) увійшли такі показники розширення сфери батьківських почуттів - 0,78; фобія втрати дитини - 0,65; гіперпротекція - 0,57.

Модель виховання базується на домінуючій, потуральній протекції. Зазвичай, такий стиль виникає тоді, коли в силу певних причин подружні стосунки між батьками порушені: немає одного $з$ подружжя (розлучення, смерть), або стосунки характеризуються сильною емоційною холодністю. Один 3 батьків прагне, щоб дитина була чимось більшим, ніж просто дитиною, і задовольняла хоча б частину обов'язків, які повинні бути задоволені в сімейних взаємостосунках (взаємна прив'язаність, підтримка).

4-й фактор (внесок в сумарну дисперсію - 7,1\%) трактували як «нестійкий, полярний стиль виховання», який склали нестійкість стилю виховання - 0,72; потурання - 0,57; надмірність обов'язків - 0,62.
Стиль виховання часто нестійкий: від жорсткого до ліберального і навпаки. Причиною такої поведінки є конфліктність у взаємостосунках пари, де виховання - «поле битви» батьків: один притримується ліберальних тенденцій, інший - суворих вимог та заборон. Характерні прояви - вираження невдоволення стилем виховання іншого члена подружжя. За таких умов, притаманні постійні зміни у стилі поведінки батьків від суворості та авторитарності до надмірної уважності та захисту. Ці дві полярні позиції чергуються 3 певною періодичністю.

Для з'ясування залежності показника перфекціонізму від стилів сімейного виховання був також використаний множинний регресійний аналіз. Залежною змінною у лінійній регресії виступив загальний показник перфекціонізму, незалежними змінними виступили стилі сімейного виховання. На основі даних множинного регресійного аналізу (MРА) виведено регресійні зв'язки, які показують значущий внесок сімейних чинників в досліджуваний феномен перфекціонізму, табл.1.

\section{Таблицุя 1}

\section{Сімейні чинники перфекціонізму студентської молоді}

\begin{tabular}{|c|c|c|}
\hline Показник & $\begin{array}{c}\text { Предиктори } \\
\text { перфекціонізму }\end{array}$ & $\begin{array}{c}\mathbf{R}^{\mathbf{2}} \\
\text { - коефіціснт дете- } \\
\text { рмінації }\end{array}$ \\
\hline \multirow{2}{*}{ Стилі сімейного виховання } & Ігнорування потреб (емоційних) дитини & 0,251 \\
\cline { 2 - 3 } & Надмірність вимог & 0,211 \\
\cline { 2 - 3 } & $\begin{array}{c}\text { Проекція на дитину власних небажаних яко- } \\
\text { стей }\end{array}$ & 0,148 \\
\hline $\begin{array}{l}\text { Показник перфекціонізму } \mathbf{y} \\
\text { батьків }\end{array}$ & & 0,127 \\
\hline
\end{tabular}


Таким чином, нами виявлено три основні стилі батьківського виховання, що впливають на формування перфекціонізму студентської молоді.

При ігноруванні потреб дитини найчастіше страждають духовні потреби, зокрема, в емоційному контакті, любові, спілкуванні з батьками.

Надмірність вимог до дитини проявляється через висунення надвисоких, непосильних завдань 3 боку батьків, що не відповідають дитячим можливостям, і не лише не сприяють розвитку іiї як особистості, а й ставлять його під загрозу.

Проекція власних небажаний якостей виникає тоді, коли батьки бачать певні якості або риси в дитині, які не приймають у собі. Борячись 3 цими об'єктивними чи уявними якостями у когось, батьки отримують емоційну вигоду для себе, адже допомагає вірити, що у них цього немає.

Досліджуючи особливості взаємозв'язків між рівнем перфекціонізму у батьків та дітей за допомогою кореляційного аналізу встановлено, що вищий рівень перфекціонізму у батьків, то вищий показник перфекціонізму у дітей, $\mathrm{r}=0,42$, рис.
Також результати регресійного аналізу вказують, що показник перфекціонізму у дітей залежить від показника перфекціонізму у батьків $\left(\mathrm{R}^{2}-0,127\right)$.

Це своє чергу, доводить, що перфекціоністичні батьки здатні виховувати перфекціоністські орієнтації у власний дітей.

Висновки. Отож, можемо сформулювати такі висновки:

* стиль (модель) сімейного виховання накладає відбиток на розвиток та формування перфекціоністських тенденцій в особистості. Що більш дисгармонійними є сімейні взаємостосунки для людини, що більше невдоволення вони викликають, то ймовірніших розвиток перфекціонізму.

* факторний аналіз дозволив виокремити чотири основні стилі, що здійснюють найбільш вагомий вклад у формуванні перфекціоністських тенденцій: «емоційне відторгнення», «авторитарний стиль», «ідеалізація дитини» та «нестійка або полярна модель виховання».

*регресійний аналіз дозволив звузити і виокремити стилі сімейного виховання, що здійснюють вплив на формування перфекціонізму: ігнорування потреб дитини, надмірність ви-

Рис. 1. Особливості взаємозв'язку перфекціонізму серед батьків та дітей

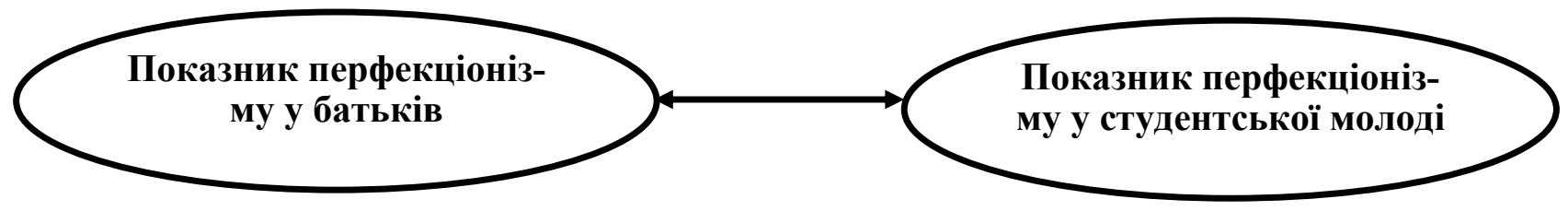


мог, проекція на дитину власних небажаних якостей, прояв перфекціонізму у батьків.

\section{Перелік використаних джерел:}

1. Гаранян Н. Г. Перфекционизм и враж дебност ь как личностные факторы депрессивных и тревожных расстройств : автореф. дис. ... канд. психол. наук .- М., 2010. -42 c.

2. Гаранян Н.Г. Психологические модели перфекционизма / Вопросы психологии. - 2009. - № 5. - С. 74-83.

3. Степанов В.Г. Психология т рудных школьников / В. Степанов. - М., 1997. - 145c.

4. Хорни $K$. Неврот ическая личност ь нашого времени /

К. Хорни. - СПб.: Питер, 2002. - 218c.

5. Чепурна Г. Л. Соціально-психологічні особливості перфекціонізму молоді : автореф. дис. на здобуття наук. ступеня канд. психол. наук: спец. 19.00.05 «Соціальна психологія психологія, соціальної роботи» / Чепурна Г. Л. - Ч., 2013. - 24 с.

6. Юдеева Т. Ю. Перфекционизм как личност ный фактор депрессивных и тревожных расстройств : дис. ... канд. псих. наук. - М., 2007. - 275 с.

7. Burns D. D. The perfectionist's script for self-defeat // Psychology Todey. November 1980. - P. $34-52$.

8. Blatt S., Quinlan D., Chevron E. Dependency and selfcriticism: psychological dimensions of depression // J-1 of Consulting and Clinical Psychology. 1982. V. 50. P. 113124.

9. Hamachek D. Psychodynamics of normal and neurotic perfectionism / Psychology. - 1978. - №15. - P. 27-33.

10. Hollender M. H. Perfectionism / Comprehensive Psychiatry. - 1965. - Vol.6. - P. 94-103.

\section{References (Transliteration):}

1. Garanyan N. G. Perfektsionizm i vrazhdebnost kak lichnostnyie faktoryi depressivnyih i trevozhnyih rasstroystv : avtoref. dis. ... kand. psihol. nauk . - M., 2010. - 42 s.

2. Garanyan N. G. Psihologicheskie modeli perfektsionizma / Voprosyi psihologii. - 2009. - \# 5. - S. 74-83.

3. Stepanov V. G. Psihologiya trudnyih shkolnikov/V. Stepanov. - M., 1997. - 145s.

4. Horni K. Nevroticheskaya lichnost nashogo vremeni / K. Horni. - SPb.: Piter, 2002. - 218s.

5. Chepurna G. L. SotsIalno-psihologIchnI osoblivostI perfektsIonIzmu molodI : avtoref. dis. na zdobuttya nauk. stupenya kand. psihol. nauk : spets. 19.00.05 «SotsIalna psihologIya psihologIya, sotsIalnoYi roboti»/Chepurna G. L. Ch., 2013. - 24 s.

6. Yudeeva T. Yu. Perfektsionizm kak lichnostnyiy faktor depressivnyih i trevozhnyih rasstroystv : dis. ...kand. psih. nauk. - M., 2007. - 275 s.

7. Burns D. D. The perfectionist's script for self-defeat // Psychology Todey. November 1980. - P. $34-52$.

8. Blatt S., Quinlan D., Chevron E. Dependency and selfcriticism: psychological dimensions of depression // J-1 of Consulting and Clinical Psychology. 1982. V. 50. R. 113124.

9. Hamachek D. Psychodynamics of normal and neurotic perfectionism / Psychology. - 1978. - \#15. - P. 27-33.

10. Hollender M. H. Perfectionism / Comprehensive Psychiatry. - 1965. - Vol.6. - P. 94-103.

\section{Zavada Tetyana}

Senior lecturer of the Department of Psychology and Psychotherapy at Ukrainian Catholic University, Lviv (Ukraine)

\section{PARENTAL PERFECTIONISM AS A FAC- TOR OF STUDENT'S MAKEOVER}

\section{ABSTRACT}

The article is devoted to highlighting the impact of styles of family education for young 
perfectionism. Theoretical achievements of psychological research on family education and its relationship with perfectionism. Excessive criticism, demanding, authoritarian parenting style, expression of love and approval only in cases of successful outcomes of their children - contribute to the development perfectionist tendencies. In the empirical study found those parenting style most characteristic for students perfectionist. It was established that a large variety of family difficulties may be associated with the formation and development of perfectionism. The results of the factor analysis indicate four dominant style of family education, engaged in the most significant contribution to the formation perfectionist tendencies of students «emotional rejection», «authoritarian », «idealization of the child» and «unstable or polar model of education». Using regression analysis, the style of family education, exercising influence on the formation of perfectionism, ignoring the child's needs, redundancy requirements, the projection of a child of their own undesirable traits. Also found (based on correlation and regression analysis) that parents are able to educate perfektsionistychni perfectionist orientation in their own children. Thus, the model of family education affects the development and formation of perfectionist tendencies of personality. What is more disharmonious family relationships to humans that they cause more discontent, the more likely the development of perfectionism.
Keywords: perfectionism, parental perfectionism, personality, style of family education, college students, authoritarian parenting style.

\section{Завада Татьяна Юриевна}

Преподаватель кафедры психологии и психотерапии Украинского католического университета, г.. Львов (Украина)

\section{РОДИТЕЛЬСКИЙ ПЕРФЕКЦИОНИЗМ КАК ФВКТОР ПЕРФЕКЦИОНИЗМА СТУ ДЕНТЧЕСКОЙ МОЛОДЕЖИ}

Аннотация. Статья раскрывает проблемы влияния стилей семейного воспитания на перфекционизм молодежи. Проанализированы теоретические исследования, касающиеся семейного воспитания и его связи с перфекционизмом. В эмпирическом исследовании обнаружено те стили родительского воспитания, наиболее характерные для перфекционистов. С помощью регрессионного анализ выделены стили семейного воспитания, оказывающих влияние на формирование перфекционизма: игнорирование потребностей ребенка, избыточность требований, проекция на ребенка собственных нежелательных качеств. Также выявлено, что перфекционистични родители способны воспитывать перфекционистские ориентации в собственный детей.

Ключевые слова: перфекционизм, родительский перфекционизм, личность, стили семейного воспитания, студенты, авторитарный стиль воспитания. 